\title{
THE FIRST DECADE OF MILITARY RULE AND ELECTORAL POLITICS IN ONDO STATE: 1976-86
}

\author{
Dr Dipo Kolawole
}

\section{Introduction}

There is the tendency to wonder about the relationship between military rule and electoral politics. This is understandable since in the advanced politics of the world, military rule is seen as an antithesis of electoral politics and civil democracy. It is believed in such politics that the survival of a civil polity can be best guaranteed if the supreme power of the state is vested in the people and exercised on their behalf by their representatives who are chosen through periodic elections. In such societies, the military establishments are saddled with, and indeed readily accept, the responsibility for the security of the state by preventing external aggression. But the role-perception of the military in the developing world is markedly different from this.

In the developing world, politics is often characterised by perennial instability which is sometimes brought about by cut-throat rivalry among the contestants for political power. Although the desire for seeking political leadership is usually anchored on a commitment to reform societal ills, yet, the pursuit of power can be desperately carried out in total disregard of the interests and feelings of the citizenry. This usually leads to a breakdown of law and thereby provides an opportunity for the military to intervene in politics.

Consequently, in most of the countries of Africa and Latin America, military rule has been the rule rather than the exception. Indeed, military rulers often attributed their intervention in politics to forces of circumstance rather than being a pre-conceived phenomenon. General Olusegun Obasanjo, a one-time military head of state of 
Nigeria, has succinctly associated himself with the argument that military intervention is caused by "circumstances of unbriddled defiance of the accepted norms and practices of democracy on the part of the political elite, their negative disposition towards unity, and consequent peace and stability of the nation and their culpable tendency towards tribal polarizations. Some years later, another military head of state, General Ibrahim Babangida, was to share the views by arguing that "the dismal management of our national economy and the bitterness and violence which characterized Nigerian politics in the oast were the causes of military intervention in our country.

Irrespective of the state and character of the arguments, one fact remains indisputable that some countries of the developing world have experienced longer periods of military rule than civil rule. Paradoxically, it can be said therefore, that military rule in these countries clearly manifests the failure of electoral politics. It is this assumption that informs this study.

The Nigerian experience aptly demonstrates this assumption. The first coup in January 1966 was, among other things, a result of disputations that attended the 1964 Federal elections and the 1965 Western Region election. Also, the military intervention of 1983 was largely due to the malpractices associated with that year's elections. Meanwhile, it is pertinent to survey briefly the history of state creation in Nigeria so as to bring out the circumstances of the emergences of Ondo State.

\section{Background to State Creation}

There have always been divergent opinions on the administrative structure of Nigeria since Lord Lugard amalgamated the Northern and Sourthern protectorates on 1 January, 1914. In 1951, the Mac-pherson Constitution introduced regionalism into Nigeria by dividing the country into three regions, namely: Northern, Western and Eastern regions. The 1954 Lyttleton Constitution, formalized the federal system of government for the country and the regions were given greater autonomy.

Nonetheless, the character of the Nigerian Federation was problematic. C. J. Friedrick has posited that:

A federation is a union of group selves, united by one or more common objectives but retaining their distinctive group-being for other purposes. Federation is, on the inter-group level, while association is on the inter-personal level. It unites without destroying the selves that are uniting, and it is meant to strengthen them in their mutual relations. 
Yet, the Nigerian federation created by the 1954 Lyttleton Constitution failed to strengthen mutual relations. The federation was an antagonistic tripod of mutually suspicious regions. This unfortunate situation was heightened by the numerical advantage which the North had over the two other regions combined.

The formation of the United Middle Belt Congress (UMBC) in 1955, under the leadership of J.S. Tarka, set in motion a spate of agitation for more states in the country. The pressure on the colonial government was so much that the 1957 Constitution Conference held in London recommended the setting up of a commission of enquiry to investigate the genuineness or otherwise of the fears of the minority groups. The Willink's Commission of 1958 concluded that the fears were real, but did not agree that the fears could only be allayed by creating more states. However, in a move that was aimed at scoring political points rather than a permanent solution to the structural imbalance in the country, the Mid-Western region was in 1963 carved out of the Western region which was then the smallest of the three regions.

Moreover, in order to contain Col. Ojukwu's secessionist ambitions during the military regime of General Gowon, Nigeria was restructured on 27 May, 1967 to become a nation of twelve states. It is significant to note that this was the first time the term "state" was used to refer to the administrative units of the country. But the restructuring was aimed more at serving a political expediency by polarising loyalty within the erstwhile Eastern region which represented Ojukwu's constituency. Hence, the move did not stop the demands for more states, though it momentarily succeeded at easing the tension created by the North's numerical strength which was feared constituted a weapon of political domination.

The Muhammed administration that succeeded Gowon's, not only promised a return to civil rule within a definite date but also made the issue of creation of more states one of the items on its programme for such disengagement. In August 1975, it appointed a panel under the Chairmanship of Mr Justice Ayo Irikefe to examine the question of state creation in Nigeria. As a result and, in line with the administration's approach to other pressing national issues, seven additional new states were created on 3 February, 1976 and this made Nigeria a federation of nineteen states ${ }^{7}$. One of the states created was Ondo State with an estimated area of 18,165 square kilometres and an estimated population of 2,727,675 people ${ }^{8}$. The State is thus a military creation.

It is significant to note at this juncture, that the two instances, when major structural adjustments were made to the Federation, were under military administrations. Yet, agitations for more states were always loudest under civilian regimes. It is also remarkable, that the Muhammed approach allowed the people to participate in open discussions of how many number of states to create. 
The First Decade of Military 111

The exercise can also be said to have succeeded in reducing the structural imbalance which has been in existence since the amalgamation of 1914.

\section{Ondo State and Military Rule}

There are various theories of military intervention in politics. S.E. Finer ${ }^{10}$ places emphasis on the character of the political culture. Alternatively, Janowitz and Huntington put premium on "the internal characteristics" and the military's level of "professionalism" respectively. However, the case of Nigeria is perhaps better explained by an amalgam of these factors. In any case, military intervention in Nigerian politics is more dramatic for its impact rather than its causes, and this is our focus here.

Ondo State, as previously mentioned, was a product of a military decision. It became a legal entity on 3 February, 1976 and, within a decade, has experienced six years of military rule as against four years of civil rule. Furthermore, within the period, it has had four military governors and only one civilian governor. ${ }^{13}$

Wing Commander David Ikpeme was appointed the first military governor of the state. He first assumed duties in Ibadan because the capital site - - Akure - was not yet ready to serve as a base of government Ikpeme's stay in Ibadan was to allow infrastructure! amenities to be provided at Akure. Ondo State was not alone in this category. The situation also applied to Ogun, another state that was carved out of the erstwhile Western State. In order to facilitate the take-off of the various states, an implementation committee was set up and Brigadier David Jemibewon, the then military Governor of the domicile Oyo State noted that:

The Committee's main duty was to ensure the smooth take-off of the newly created states by effectively arranging equitable distribution of personnel and assets of the former Western State of Nigeria ..... it was also the duty of the Committee to arrange a painless dissolution of all the organs of the former Western State such as statutory corporations and boards, while each state was left to determine which $\mathrm{o}^{\wedge}$ the corporations and boards it would replicate. ${ }^{14}$

Assets and liabilities of the former Western State were shared among the three new states in the ratio of 44: 31: 25 for Oyo, Ondo and Ogun States respectively. ${ }^{15}$ The implementation committee was dissolved in September 1976 after the completion of its statutory duties. On 1 April, 1976, Governor Ikpeme moved to the new state capital and appointed nine commissioners to assist him in the state administration. 


\section{Annals of the Social Council of Nigeria}

David Ikpeme and his team of commissioners gave the new state a Grm footing until he was reposted on 24 July, 1978 was a result of the demilitarisation programme of the Obasanjo regime. A new military administrator, Brigadier S.E. Tuoyo, administered the state until 1 October, 1979 when civil rule was restored. There was a civilian interregnum of four years after which Commodore Bamidele Otiko assumed office as military governor after the coup of 31 December, 1983. He was, in turn replaced by Navy Captain Michael Akhigbe after the 27August, 1985 coup d'etat.

The creation of Ondo State in 1976 was signifiant because it coincided with the end of the concept of imperial military governorship which was the norm under the Gowon administration. Under Gowon, military governors acted like provincial kings who were only nominally responsible to their overlords in Lagos. Indeed, public dissatisfaction with this mode of leadership and, in particular, the imperial rulership style of most of the state governors were critical elements in the overthrow of Gowon's regime. Thus, in the dispensation that succeeded him - - the Muhammed/Qbansanjo administration, military governors were made accountable for their actions to the federal authorities in Lagos. Major-General JJ. Oluleye, a member of the Supreme Military Council and the Federal Executive Council during the period and who incidentally was from Ondo State captured this reality when he observed that military governors "were replaced by new ones with a difference in that the loose control of governors characteristic of Gowon's administration was nailed in the coffin while new governors were shielded from local influences by sending them to states other than their own". ${ }^{16}$ The resultant effect was that "nobody ever degenerated to the level of Gowon's governors". ${ }^{17}$

Thereafter, it became clear that the post of a military governor was a simple military posting, implying that an incumbent governor could be removed at will. This uncertainty of tenure, encouraged restraint and moral rectitude on the part of incumbents. State military governors were, therefore, able to follow very religiously the broad policy outlines from Lagos and this facilitated proper conduct in the supervision of elections which preceded the onset of civilian rule.

\section{Onde State and Electoral Politics: Some Theoretical Considerations}

In competitive political systems, elections bind the citizenry closer to the political process. Thus, elections contribute significantly to the stability of the system. Elections serve four major functions namely: selection, information, serialization/integration and legitimation. ${ }^{19}$ Accordingly, Richard Rose and Harve Mossawir have noted: 
Elections are among the most ubiquitous of contemporary political institutions and voting is the single act of political participation undertaken by a majority of adults in a majority of the nations in the world today. ${ }^{20}$

This does not imply that electorates are usually rational in their choice of candidates. Indeed, the decision to vote for a particular candidate may not necessary be based on policy considerations.

Several theories have been advanced by scholars to explain the factors that influence voting behaviour. ${ }^{21}$ Three of the theories will suffice for this analysis. ${ }^{22}$ First, is the "social group theory" which holds that individuals vote as a result of the influences of the social groups to which they belong. Second, is the "cue theory" which states that party programmes influence electorates in voting in a specific way. Third, is the "rational choice theory". In this respect, the electorate sees itself as a consumer who is seeking the best value for its money. It measures issues on the basis of the benefits and costs to itself ensuring that the benefits gained exceed the probable costs. ${ }^{23}$

Any of these theories or a combination of them may explain the voting behaviour of electorates. Significantly, however, elections serve as a symbolic exercise for the psychological upliftment of the populace. To this end, a scholar has argued that the real essence of elections is to quiet resentments and doubts about particular political acts, reaffirm belief in the fundamental rationality and democratic character of the system and thus fix conforming habits of future behaviour". ${ }^{24}$ However, this is not always the case.

Electoral politics was first introduced in Nigeria during the colonial period and at that point in time, it was simply an agent of participatory politics. Hugh Clifford, the colonial Governor, first introduced the elective principle to Nigeria under the 1922 Constitution. The process was sequential. First, as historian Tekena Ta-muno observes, "the franchise was first allowed in municipal or town council elections before this privilege was extended by the British authorities to the selection of legislative council". ${ }^{2 *}$ The criteria have changed from time to time. In 1950, electoral representation was on an equal basis between the North and the South. In 19S4, election in the North was through the indirect means while it was direct election in the West and East. Since 1959, representation has always been based on population. 


\section{Annals of the Social Council of Nigeria}

In its ten years existence, however, Ondo State has gone through four elections. Three of them were conducted under military rule. These were the 1976 local government elections, the 1977 constituent assembly elections and the 1979 elections. The 1983 elections were the only elections conducted under a civilian regime. Analysis of the relationship between military rule and electoral politics requires a consideration of these various elections.

\section{(i) THE 1976 LOCAL GOVERNMENT ELECTIONS}

The Local Government elections held on 28 December, 1976 were significant in at least two ways. One, it was the first election in Nigeria since the military took over the administration of the country in January 1966. Two „, it attested to the irrevocable commitment of the Muhammed/Obasanjo regime to hand over the reins of government to a civilian administration as promised.

In Ondo State, the state steering committee on local government elections was under the chairmanship of Professor D.F. Ojo. It was invested with the responsibility for the elections and it carried out its duties diligently. In consequence, the elections were conducted peacefully in the seventeen local governments. Military performance in this regard was far better than its civilian antecedent in that the last election in Ondo areas, when it was still part of the old Western State was held on 11 October, 1965 and was marked by arson and rioting. Indeed, it is generally believed that the state of affairs in the then Western Region was the immediate cause of military incursion into the nation's politics.

The situation under the military was markedly different. Many of the candidates in the local government elections of 1976 were returned unopposed, implying the consensus of the electorate on the ability of such candidates. Furthermore, the nomination and selection of the chairmen for the local governments were done without rancour. In the past, instead of local governments being the unit of development they were the unit of entrenching corruption in the body politic of the nation. Abuse of office was rampant. This realization must have informed the declaration of Governor David Ikpeme who warned that "no councillor is expected to have business transactions or enter into any contract, directly or indirectly, with the local government in which he is a member or use his official position to confer underserved benefits financial or material, to members of his family or relations". ${ }^{27}$

In order to show that the government was committed to the effective and efficient functioning of the local governments, it made grants of N1.9 million available to the local governments in addition to the-^^5 million from the Federal Government. ${ }^{28}$ Also, a 
local government loans board with an initial capital or N2.5 million was established to assist in providing loans for capital projects. The governor stressed that "this is a sizeable sum of money and local governments will have no excuse whatsoever for not performing".

It must be noted, however, that the local government elections of 1976 were not devoid of problems. Indeed, one of the towns in the State, Efon-Alaaye, refused to participate in the elections. This move was to protest the removal of the headquarters of the Ekiti West Local Government from the town to neighbouring Aramoko- Ekili. EfonAlaaye citizens argued that under the previous Western Region Local Government Law of 1955, Efon-Alaaye was made the headquarters of the locaj government and they could not see any justification for the removal of the headquarters after eighteen years. They further stated that according to the 1963 census figures, Efon-Alaaye was the most populous town in the local government area and thus was more qualified to be its headquarters.

The Efon-Alaaye situation persisted under the Tuoyo administration as the town refused to have anything to do with the local government. Thus, the civilian administration of Governor Adekunle Ajasin (1979-1983) had to create special administrative headquarters for the town and subsequent administrations, though military, have not disturbed this arrangement.

A lesson can be learnt from the Efon situation which is a candid testimony that while a state of relative stability and peace inheres in military dominance, erroneous decisions are often taken. It is difficult, for instance, to understand the reasons for the action of the Ikpeme government since no plausible one was proffered. The decision to change tne local government headquarters had serious implications for order and peaceful coexistence in the local government area. The shift of headquarters created unnecessary enmity, disharmony and rancour. Yet, the military embarked on it without any apparent justification providing concrete proof, if any was needed, that peace and stability under the military was a function of military monopoly of the active instruments of violence.

\section{(ii) CONSTITUENT ASSEMBLY ELECTIONS}

The constituent assembly elections of 1977 was the next exercise in electoral politics. Local government councillors elected in 1976 were expected to serve as an electoral college for the choice of members of the constituent assembly and since partisan politics remained banned, the contest was based on individual merit. Seats were allocated on the basis of equality and population: fifty per cent in each category. The Supreme Military Council also nominated twenty members to the assembly to represent special interests which were perhaps not adequately taken care of in the elections. 
The constituent assembly elections were help on 31 August, 1977. Ten seats were allocated to Ondo State and nine out of the seats were contested while the candidate for Owo was returned unopposed.

One interesting aspect of the constituent assembly elections in the state is in relation to the two individuals who were to play very prominent roles in the states politics between 1979 and 1983. First, Chief Adekunle Ajasin who emerged the first civilian governor of the new state from 1979 to 1983 did not contest the elections. Instead, he made sure that the candidate from his constituency won unopposed. Two, Chief Akin Omoboriowo, deputy governor under the Ajasin administration and the NPN's governorship candidate in the 1983 elections, contested the elections in Ekiti West/Ijero constituency and lost with seven votes to Mr S.O. Apetuje's sixteen votes. Also, Mrs Comfort Apetuje (the wife of Mr Apetuje,) contested and lost the 1979 House of Representatives elections in Ekiti West constituency on the platform of the National Party of Nigeria (NPN) to Prof. Opeyemi Ola who constested and won on the platform of the Unity Party of Nigeria (UPN). It is also significant to note that the elections were conducted under peaceful atmosphere and that no candidate felt rigged out of winning.

\section{(iii) THE 1979 ELECTIONS}

One recurrent pattern of military activity once they take over power in the developing world is to outlaw political parties. The reason for this stems from two major premises. One is to ensure that no forum for a counter-offensive through political gatherings is allowed by the new regime. Two, political parties in the developing world are very powerful as a uniting force for diverse people, and because of charisma and appeal of their various leaders, they (political parties) may serve as a centre for generating political acrimony.

The military in Nigeria followed the usual pattern on taking over power in 1966, they outlawed the existence of political parties. Also, the assets of all the political parties were confiscated. When they held elections, as was the case in 1976 and 19.77, which WS have examined earlier, they did so without allowing political parties to serve as the base for political allegiance.

However, the situation could not continue indefinitely, particularly as the military had plans to return the government to civil rule. Thus, the Muhammed/Obasanjo regime announced a precise time table and was scrupulous in adhering to it. Decree 73 of 1977 established the Federal Electoral Commission which was to conduct all elections for the return to civil rule. On 21 September, 1978 General Obasanjo lifted the ban on political parties urging that: 


\section{The First Decade of Military 117}

From now on, let the game of politics be played according to the laid down rules. Let all players be good sportsmen. No matter the result of the competition, let all players remain friendly and without bitterness, looking forward to another competition. ${ }^{34}$

Five major political parties were registered by the Federal Electoral Commission. V. O. Key Jr, has stressed that political parties are the "basic institutions for the translation of mass preferences into public policy". This position is also shared by the Italian political scientist, Giovanni Sartori, who posited that "a party-less polity cannot cope, in the long run, with a politicized society", After thirteen years of military rule, Nigerians agreed with this assessment and joyfully welcomed the lift of the ban on political parties. The result was that Ondo State like the other states in the federation, witnessed another election in 1979. But this time and for the first time since its inception, with political parties as the base of allegiance.

Previous elections in Nigeria had shown that the present Ondo State had always constituted a strong political base for Chief Obafemi Awolowo, the leader of the UPN. Such is the adulation in which Chief Awolowo was held, that any opposition to his political views was considered in this part of the country as a sacrilege. Even as early as the 1959 elections, one of the towns in the new state felt insulted by an attempt by a rival political party to come and campaign in the town. The effect was, as K, W. J. Post puts it, that "the most serious clash (during the 1957 elections) occurred in the West at EfonAlaaye in Ekiti Division" between Awolowo's Action Group supporters and Azikiwe's National Council of Nigerian Citizens' supporters who had come from the neighbouring town of Ilesha to campaign.

The 1979 general elections held between 7 July, 1979 and 11 August, 1979 showed clearly that in spite of the long period of military interregnum, the popularity of Chief Awolowo was not waning in Ondo State. The UPN won all the five senatorial seats allocated to the State with a total of 501,492 votes or $89 \%$ of the votes cast while the next party to it - the NPN - scored 49,612 votes or $8.8 \%$ of the total votes cast in the State. ${ }^{40}$ The UPN's also won all the twenty-two seats to the House of Representatives by scoring 755,612 votes or $91.63 \%$ of the votes to the NPN's 55,688 or $6.75 \%$ of the total votes cast in the State. The UPN also secured sixty-five of the sixty-six State Assembly seats conceding only a seat to the second strongest party in the State, the NPN. In terms of popular votes, the UPN scored a total of 830,102 votes or $91.53 \%$ of the votes cast in the State to NPN's 58,973 or $6.50 \%$ of the votes. ${ }^{42}$ The UPN easily won the gubernatorial elections in the State with an overwhelming 1,007,491 
votes or $94.78 \%$ of the votes to NPN's 48,975 or $4.61 \%$ of the votes. In the presidential elections the UPN scored 1,294,663 votes or $94.51 \%$ of the votes for Chiet Awolowo while the NPN's candidate Alhaji Shehu Shagari scored only 57,388 or $4.19 \%$ of the votes. $^{44}$

Some deductions can be made from the 1979 elections results in Ondo State. One is that there was an overwhelming mono-party loyalty in favour of Awolowo's UPN. Two is that electorates in Ondo State were unambiguously supportive of Chief Awolowo as a person, as revealed in the presidential elections results. For example, not only that he did not score up to $94.51 \%$ in any other State including his home State of Ogun where he scored $92.61 \%$ of the votes cast, but also that no other presidential candidate scored close to that mark in any of the States, furthermore, it is only in Ondo State of all the nineteen states that the governorship candidate (UPN) scored up to and more than one million votes. Also, Chief Awolowo scored the highest votes by any presidential candidate in any local government in Ekiti West Local Government of Ondo State where he scored $98.23 \%$ of the votes. Indeed, it can be said that the one scat won by the NPN in the State assembly elections was due to local opposition to the person of the UPN candidate rather than a sociological manifestation of any avowed loyalty to the NPN. This analysis provides an efficient parameter for comparing the civilian elections of 1983 with its military precedents.

\section{(iv) THE 1983 ELECTIONS}

The 1983 elections in Ondo State can be said to fall into the category of elections which V.O. Key Jr., has termed "critical elections". The reason for this lies in a major event that intervened between the elections of 1979 and 1983 within the ruling government of the UPN. It relates to intra- party rivalry within the ruling UPN. The Deputy Governor of Ondo State, Chief Akin Omoboriowo, defected to the rival NPN party and became its governorship candidate.

The party loyalists within the UPN believed and expected that the defection of Omoboriowo would not have any significant effects on the outcome of the elections. Onthe other hand, the Omoboriowo group assumed that it was an opportunity to break the Awo myth and the cult of personality dominating the UPN. The theatre for testing the hypotheses was the governorship elections which set the stage for the battle royal between UPN as represented by Ajasin and the NPN personified by the new entrantOmoboriowo.

Meanwhile,, the presidential elections held on 6 August, 1983 had shown that the Omoboriowo group had at least a foothold of the votes cast in the state while Alhaji Shehu Shagari scored $20.03 \%$ of the votes. ${ }^{49}$ But the dramatic "defeat" of UPN in the governorship 
elections set the State ablaze. Before it could be resolved judicially in favour of the UPN, many lives and property had been lost. It took barely four months before the military intervened again in Nigerian politics. By then, not many people were surprised as it seemed the civil rulers were incapable of administering the polity.

\section{Conclusion}

A decade of military rule and electoral politics in Ondo State has had several notable implications. First, the military must be credited with the foundation of the State. Second and more paradoxical, is that they have conducted more peaceful and more credible elections than their civilian counterparts. Although the Ikpeme administration made a costly mistake in relation to the Efon-Alaaye episode of 1976, on balance, it is a significant area of achievement for them. Finally, the military succeeded in restoring confidence among the diverse people of the State after the events of 1983. However, the military record is not remarkable in the areas of industrialisation and the provision of infrastructure.

In contrast, the civilian government recorded creditable achievements in the areas of tertiary education and banking. The Ajasin administration created a University and a bank. Yet, it was not able to sustain a democracy. Political competition was perceived as zero-sum game in which one man's gain was the other's loss and this resulted in violence and the bastardisation of the electoral process.

This then, is the enduring riddle of electoral politics in Ondo State. The military who are themselves the antithesis of the electoral process managed to conduct more realistic and acceptable elections, free of malpractices and violence than their civilian counterparts for whom elections are a raison d'etre. However, the problem is not as localised as it may seem. Ondo State is a representative sample of what was happening everywhere else in the federation. An inherent crisis of Nigerian politics is that the military are better able to provide the safeguard and the atmosphere of stability needed for orderly elections. Depressingly enough, until this difficulty is solved, electoral politics in Nigerian would remain a nightmare under civilian regime. 


\section{Notes}

1. $\quad$ See West Africa, London: 24 July, 1978, p. 1421.

2. See The Guardian, 10 September, 1991. In fact, the different perception of the role of the military in politics by the developed and developing countries were presented at the recent opening of the Second Conference of the Body of Attorneys-General in Nigeria at Abuja on 9 September' 1991 by the American Vice-President, Dan Quayle and General Babangida.

3. For details, see Federal Military Government Views on the Report of the Panel on Creation of States, Lagos: Federal Ministry of Information, 1976. See especially items 6 \& 7 where the proposals of E. D. Morel and C.L. Temple for the breaking of the nation into Smaller states are discussed in detail.

4. Quoted in Uma O. Eleazu, Federalism and Nation-Building: The Nigerian Experience, 1954-1964, Ilfracombe Devon: Arthur H. Stockwell Ltd, 1977, p. 16.

5. The Western Region was-the political base of the Action Group (AG) which was the opposition party in the federal parliament. Thus, the Federal Government's decision was seen as an attempt to undercut the AG.

6. The 12 states were Bcnuc/Platcau, East Central, Kano, Kwara, Lagos, MidWestern, North-Central, North-Eastern, North- Western, Rivers, South Eastern and Western.

7. The 19 States were Anambra, Bauchi, Bendcl, Benue, Borno, Cross River, Gongola, Imo, Kaduna, Kano, Kwara, Lagos, Niger, Ogun, Ondo, Oyo, Plateau, Rivers and Sokoto.

8. $\quad$ See Federal Military Government Views, op. cit, p. 32.

9. The agitation reached a ridiculous level between 1979 and 1983. The politicians deceitfully encouraged agitators even though the 1979 Constitution created a cumbersome procedure for state creation. It is, however, significant to note that there are now 30 States in Nigeria.

10. S.E. Finer, The Man on Horseback, London: Pall Mall Press, 1962.

11. Moris Janowitz, The Military in the Political Development of New Nations, Chicago: University of Chicago Press, 1964.

12. S.P. Huntington, The Soldier and the State, Cambridge Mass: Harvard University Press, 1967.

13. They are Wing Commander David Ikpeme, February 1976-July 1978; Brigadier S.E. Tuoyo, (Military Administrator), 1 July, 197830 September, 1979; Chief Adekunle Ajasin,(the only civilian Governor to-date) 1 October, 1979 -31 December, 1983; Commodore M.B. Otiko, 5 January, 
1984-27 August, 1985; Commodore Mike Akhigbe, 2 September, 1985 - 25 August, 1986. Since then, there have been other military governors such as Brigadier Ekundayo Opaleye, August 1986 • December 1987; Navy Captain Olabode George, 17 December, 1987 - 2 September, 1990 and Navy Captain Sunday Olukoya, 3 September, 1990 to date.

14. D. M. Jemibewon, A Combatant in Government, Ibadan: Heinemann Educational Books (Nig.) Ltd., 1978, p. 96.

15. Ibid.

16. J. J. Oluleye, Military Leadership in Nigeria, 1966- 1979 Ibadan: University Press Ltd., 1985, p. 169.

17. Ibid.

18. This section of the paper benefits significantly from a previous work, see Dipo Kolawole, "Political Violence: A Case Study of Ondo State" in Victor Ayeni and Kayode Soremekun (eds) Nigeria's Second Republic, Lagos: Daily Times Publications, 1988, pp. 135-36.

19. B. J. Dudley. Instability and Political order: Politics and Crisis in Nigeria, Ibadan: Ibadan University Press, 1973, p. 58.

20. Richard Rose and Harve Mossawir, "Voting and Elections: A Functional Analysis". Political Studies, 15,1967, p. 173.

21. For example, see Ian Budge and Dennis Farlie, Voting and Party Competition, Oxford: Oxford University Press, 1977.

22. Billy J. Dudley. "The Nigerian Elections of 1979: The Voting Decision", The Journal of Commonwealth and Comparative Politics, 19, November. 1981. p. 289.

23. See also, Anthony Downs: An Economic Theory of Democracy, New York: Harper \& Row, 1957.

24. Murray Edelman, The Symbolic Uses of Politics. Urbana: University of Illinois Press, 1964, p. 17.

25. Tekena Tamuno, Nigeria and Elective Representation 1923-1947, London: Morrison and Gibb Ltd. 1966, p. 18.

26. For details of the election results, see Daily Sketch, 4-5, January 1977.

27. See Daily Sketch, 23 January, 1977, p. 14

28. See West Africa, London: 13 June, 1977, p. 1158.

29. Ibid.

30. Ibid.

31. See Daily Sketch, 10 January, 1977, pp. 6-7.

32. According to the figures, the census figures for the eight towns/villages that constituted the Local Government were, Efon-Alaaye, 67,000; Okemesi, 30,000; Aramoko, 26,000; Erinjiyan, 16,000; Ido-Ajinare, 8,000; Ipole-Iloro, 8,000, Erio, 7,000and Ikogosi, 6,500. 


\section{Annals of the Social Council of Nigeria}

33. This was in fulfillment of its election promise. In fact, the House of Representatives' seat for the Local Government in the 1979 elections was conceded by the UPN to Efon-Alaaye candidate in order to placate the town.

34. See West Africa, 2 October, 1978, p. 1935.

35. The parties were: The National party of Nigeria (NPN), The Unity Party of Nigeria (UPN), The Nigerian People's Party (NPP), The Great Nigerian People's Party (GNPP) and the People's Redemption Party (PRP). For details of the / formation process of the parties, see Toyin Falola and Julius Ihonvbere. The Rise and Fall of Nigeria's Second Republic, London, Zeb Books Ltd. 1985, pp. 46-65.

36. V. O. Key Jr, Public Opinion and American Democracy, New York: Alfred Knopf, 1961 p. 433.

37. Gwuanni Sartori, Parties and Party Systems, Vol. 1, Cambridge Mass: Cambridge University Press, 1976, p. 41.

38. For example, see K W. J. Post, The Nigerian Federal Elections of 1959, Oxford: Oxford University Press, 1963; Billy J. Dudley; An Introduction to Nigerian Government and Politics, Ibadan: Macmillan Press Ltd. 1982.

39. K. W. J. Post, The Nigerian Federal Elections of 1959, op. cit, p. 295.

40. See Billy J. Dudley; An Introduction to Nigerian Government and Politics, op. cit, p. 203.

41. See Ahmadu Kurif, The Nigerian General Elections, 1959 and 1979. and the Aftermath, Ibadan: Macmillan (Nig.) Publishers Ltd, 1983, p. 268.

42. Ibid, p. 270.

43. Ibid, p. 271.

44. Billy Dudley, op. cit, pp. 207-208.

45. Ibid, p. 208.

46. See Ahmadu Kurif, op. cit, 271.

47. Ibid,p.2S7.

48. For details See V. O. Key Jr, "A Theory of Critical Election", Journal of Politics, Vol. 17,1955.

49. Toyin Falola and Julius Ihonvbere, The Rise and Fall of Nigeria's Second Republic, 1979-1984, op. cit, p. 220.

50. For details of the turmoil, see Dipo Kolawole, op. cit, pp. 135-44. 